\title{
Analysis of differential heaving distress in soil-structure interactions due to degradation of founding soil by chemical contaminations
}

\author{
Rajesh Kumar',*, V. Kumar', K.K. Pandey', K.K. Pathak', P. Maiti', Suresh Kumar' \\ (I) Department of Civil Engineering, Indian Institute of Technology (BHU), Varanasi-22 I005, India
}

\section{Auteur correspondant : rkumar.civ@iitbhu.ac.in}

\begin{abstract}
In the process of rapid industrialization, land degradation is being observed in presence of chemical or other alterations in the natural soil. Expansive soil resulting from penetration of liquor in to the ground creating differential heaving stress in the foundation of the structures. Present paper deals a case study of distressed structure founding on the soil which is being contaminated with caustic liquor resulting from the process of manufacturing of Alumina. A reinforced cement tertiary thickener structure of Alumina plant (in India) rests on concentric columns got distress features in the form of upheaval of footings after fouryear of commissioning. The concrete and soil in the foundation area got contaminated with caustic liquor resulting in to the expansion of materials near to the foundation and creating differential heaving distress in the foundation and columns. This paper also deals the remedial measures and a methodology to make the structure stable and durable.
\end{abstract}

KEYWORDS: expansive soil, heaving stress, caustic liquor 


\title{
Analysis of differential heaving distress in soil-structure interactions due to degradation of founding soil by chemical contaminations
}

\author{
Rajesh Kumar, V. Kumar, K.K. Pandey, K.K. Pathak, P. Maiti, Suresh Kumar
}

\section{Introduction}

Land degradation in industrial areas is a big problem (Calace et al., 2005) for structures lie on the soil land. Structures got distressed due to heaving stress resulting from expansion of soil in presence of chemical in the natural soil. It has also been noticed that stability of structures got disturbed due to differential heaving stress. Ivan et al., (2009) have studied the effects of acidic contamination on the geotechnical properties of marine soils in Japan. They have conducted the laboratory investigation on marine deposits in order to study the effects of acid contamination on geotechnical properties of the soils from coastal areas of the Japan. Thusoo et al., (2015) have studied the response of building with soilstructure interaction with varying soil type. They have used finite element method in evaluating the response of the building under dynamic loading. Paulose et al., (2014) have studied swell potential of soil contaminated with $\mathrm{NaOH}$ solution. They have discussed on swelling induces in soils due to soil-alkali interaction and morphological changes occurring in the soil.

Present paper deals with a case study of distressed Reinforced Concrete Structure (RCC) founding on the soil contaminated with caustic liquor resulting from the process of manufacturing of Alumina (Hidalco Indusries Limited in India 2017). For sake of brevity, chemical reactions and morphological process of swelling induces in soils have not been reported here.

A RCC tertiary thickener structure (figure I) of Alumina plant rests on concentric columns got distress features in the form of upheaval of footings after four year of commissioning. The concrete and soil in the foundation area got contaminated with caustic liquor resulting in to the expansion of materials near to the foundation and creating differential heaving distress in the foundation and columns. This paper also deals the remedial measures and a methodology to make the structure stable and durable.

A site visit was conducted for assessing the health of structure. Four different tests have been proposed for knowing the health of the distressed structure. Ultrasonic pulse velocity (UPV) test, Rebound hammer test, half cell potential test and vibration test have been recommended here to ascertain the extent of deterioration of the materials of the structure. The main objectives of the tests are to know the current adequacy and health of the existing structure. After analysis of the test results, remedial measures have been suggested. A proper drainage system for caustic liquor has also been suggested to avoid its contamination with soil.

Ultrasonic pulse velocity (UPV) test gives the homogeneity of the concrete which establish the presence of cracks, voids and imperfection in the concrete. The quality of concrete depends upon the velocity of pulse, generated through UPV instrument (figure 2), passes through the body of concrete structure. If the velocity of pulse is above $4.5 \mathrm{~km} / \mathrm{sec}, 3.5$ to $4.5 \mathrm{~km} / \mathrm{sec}, 3.0$ to $3.5 \mathrm{~km} / \mathrm{sec}$ and below $3.0 \mathrm{~km} / \mathrm{sec}$ the quality of concrete will come in the category of excellent, good, average and doubtful category respectively (figure 4).

Rebound hammer test assess the compressive strength of concrete with the help of co-relation between rebound index and compressive strength. It works when the plunger of rebound hammer is pressed against the surface of the concrete. The spring controlled mass rebounds and extant of such rebound depends upon the surface hardness of concrete. The rebound is read off along a graduated scale and is designated as the 'Rebound Number' or 'Rebound Index' (figure 5). The probable accuracy of concrete strength in a structure is $\pm 25 \%$.

Half Cell Potential Test (figure 3) gives the extent of corrosion of the reinforcing steel in the concrete structure. It works on the potentials measures with the help of props at the two location on the surface of the concrete. If potentials over an area are more positive than -200 mV Copper Sulphate Electrode (CSE), there is a greater than $90 \%$ probability that no reinforcing steel corrosion is occurring in that area at the time of measurement. If potentials over an area are in the range of -200 to $-350 \mathrm{mV}$ CSE, corrosion activity of the reinforcing steel in that area is uncertain and if potentials over an area are more negative than $-350 \mathrm{mV}$ CSE, there is a greater than $90 \%$ probability that reinforcing steel corrosion is occurring in that area at the time of measurement (figure 6).

Vibration test gives the range of vibration of foundation of the structure. The amount of vibration can be compared with the acceptable range. This test gives the acceleration, velocity, displacement and frequency of vibration of the foundation. The average test value of vibration can be compared with 


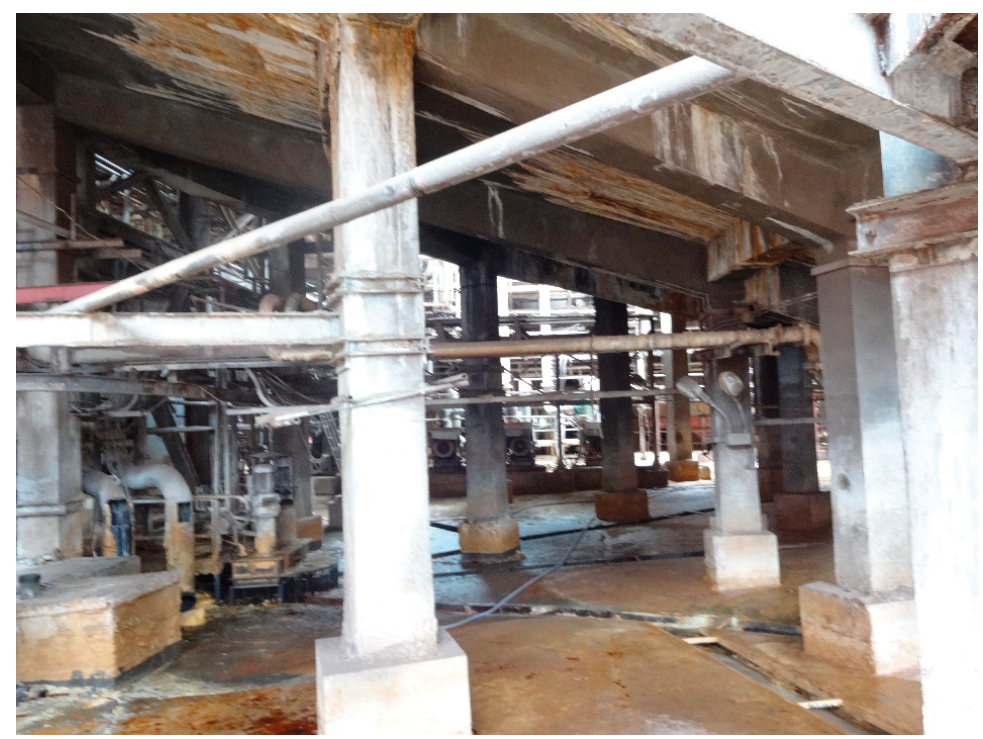

Figure I. A RCC tertiary thickener structure of Alumina plant rests on concentric columns

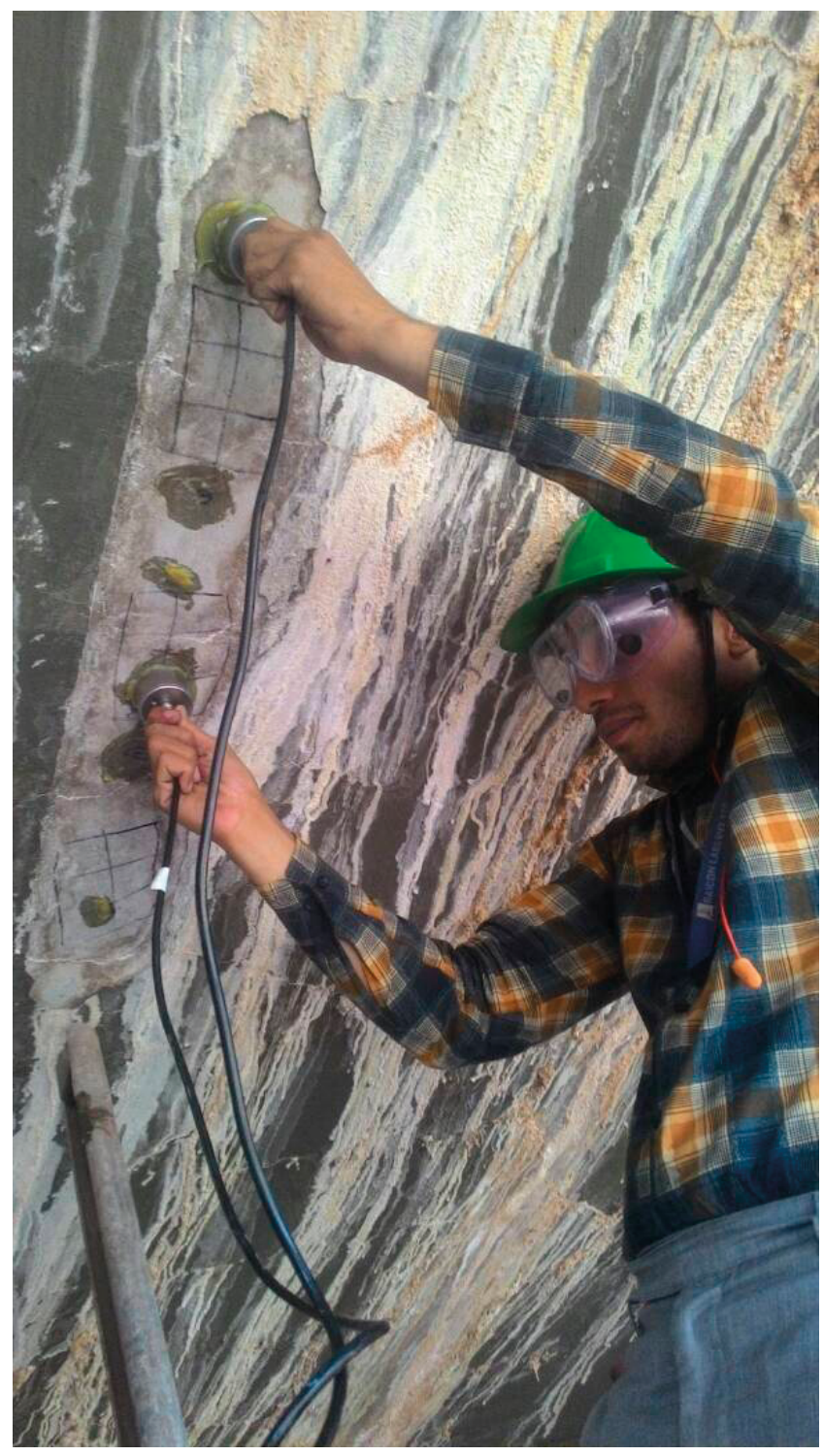

Figure 2. Ultrasonic pulse velocity test

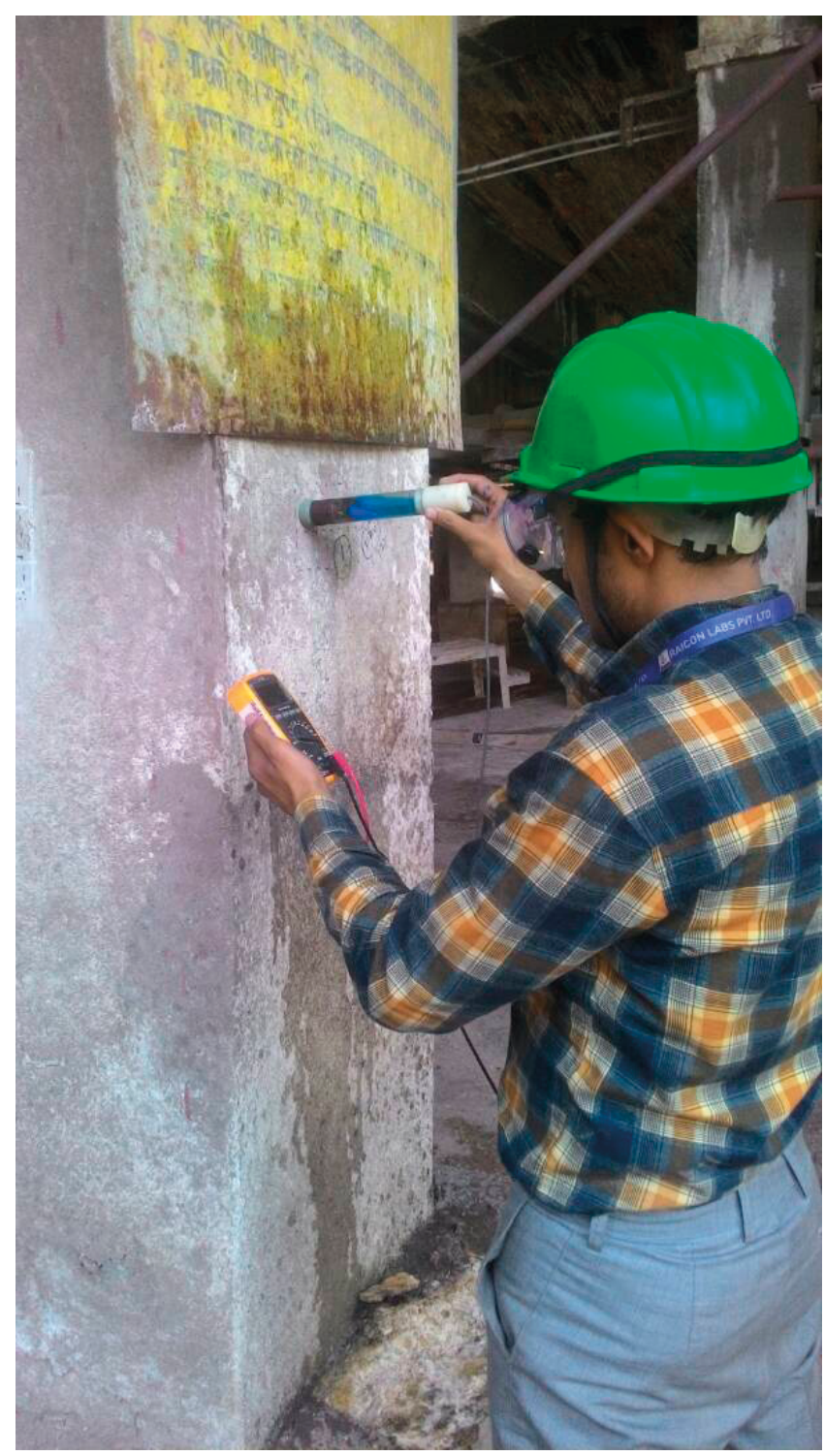

Figure 3. Half Cell Potential Test 


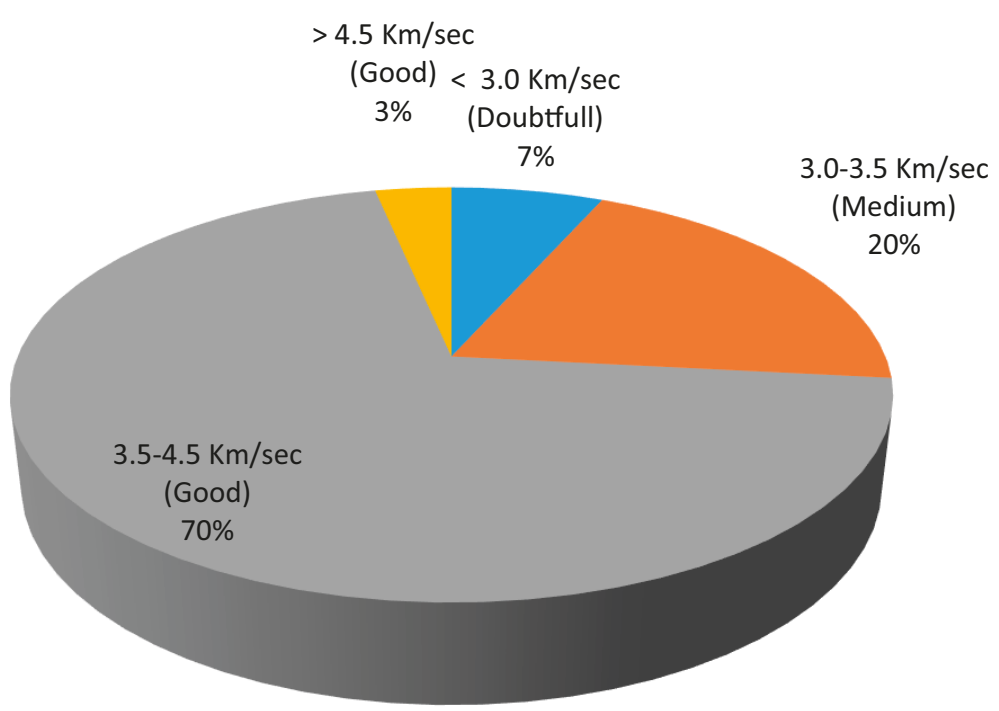

Figure 4. Ultrasonic Pulse Velocity test results for concrete

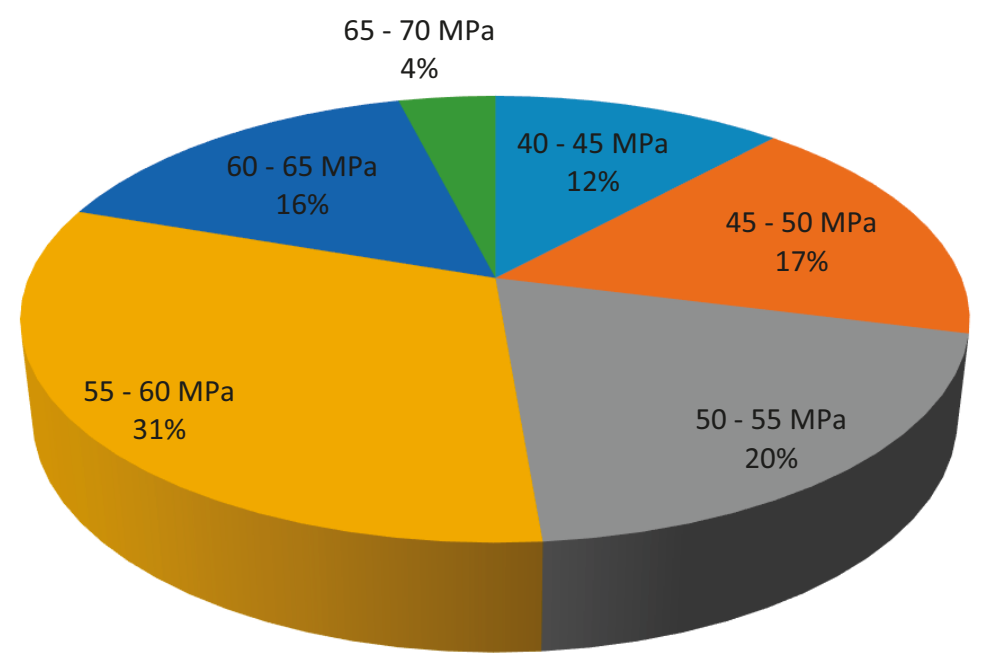

Figure 5. Rebound Hammer test results

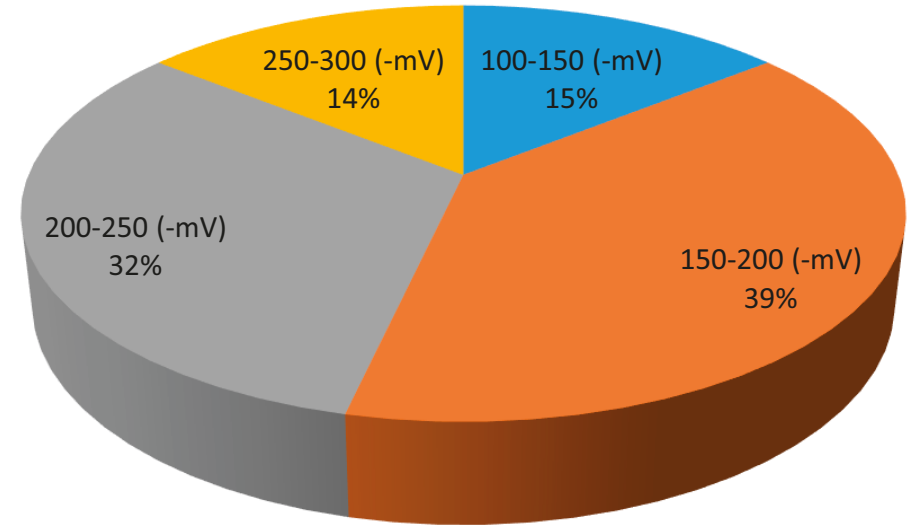

Figure 6. Half Cell Potential test results 
Table I. Vibration Test Results

\begin{tabular}{|c|c|c|c|c|c|}
\hline S.No & Location & Parameters & $\begin{array}{l}\text { Average } \\
\text { Test Value }\end{array}$ & Requirement & $\begin{array}{c}\text { Method of } \\
\text { Test }\end{array}$ \\
\hline & & Acceeration, $\mathrm{m} / \mathrm{sec}^{2}$ & 2.7 & $0.1-400$ & \\
\hline \multirow[t]{4}{*}{ I } & Column No.I & Velocity, $\mathrm{mm} / \mathrm{sec}$ & 1.60 & $0.01-400$ & \\
\hline & & Displacement, mm & 0.128 & $0.001-4.000$ & \\
\hline & & Frequency, $\mathrm{Hz}$ & 146 & $10-1000$ & \\
\hline & & Acceeration, $\mathrm{m} / \mathrm{sec}^{2}$ & 2.05 & $0.1-400$ & \\
\hline \multirow[t]{4}{*}{2} & Column No.2 & Velocity, $\mathrm{mm} / \mathrm{sec}$ & 0.71 & $0.01-400$ & \\
\hline & & Displacement, mm & 0.310 & $0.001-4.000$ & \\
\hline & & Frequency, $\mathrm{Hz}$ & 135 & $10-1000$ & \\
\hline & & Acceeration, $\mathrm{m} / \mathrm{sec}^{2}$ & 1.8 & $0.1-400$ & \\
\hline \multirow[t]{4}{*}{3} & Column No.3 & Velocity, mm/sec & 0.89 & $0.01-400$ & BS-4675 \\
\hline & & Displacement, mm & 0.282 & $0.001-4.000$ & \\
\hline & & Frequency, $\mathrm{Hz}$ & 141 & $10-1000$ & \\
\hline & & Acceeration, $\mathrm{m} / \mathrm{sec}^{2}$ & 1.6 & $0.1-400$ & \\
\hline \multirow[t]{4}{*}{4} & Column No.4 & Velocity, $\mathrm{mm} / \mathrm{sec}$ & 1.63 & $0.01-400$ & \\
\hline & & Displacement, mm & 0.374 & $0.001-4.000$ & \\
\hline & & Frequency, $\mathrm{Hz}$ & 150 & $10-1000$ & \\
\hline & & Acceeration, $\mathrm{m} / \mathrm{sec}^{2}$ & 2.4 & $0.1-400$ & \\
\hline \multirow[t]{3}{*}{5} & Column No.5 & Velocity, $\mathrm{mm} / \mathrm{sec}$ & 1.80 & $0.01-400$ & \\
\hline & & Displacement, mm & 0.207 & $0.001-4.000$ & \\
\hline & & Frequency, $\mathrm{Hz}$ & 132 & $10-1000$ & \\
\hline
\end{tabular}

requirement value as given in the BS-4675. The acceptable range of acceleration and frequency are as 0.1 to $400 \mathrm{~m} / \mathrm{sec}^{2}$ and 10 to $1000 \mathrm{~Hz}$ respectively. For sake of brevity vibration test results are not shown here. There are five columns base have been selected for vibration test and results are tabulated in table I.

\section{Results and discussions}

Ultrasonic test shows most of the concrete in sound condition with no honeycombing and 73 \% falls in good category. Some sections are under medium quality, very few under doubtful which needs to be repaired with suitable material.

From rebound hammer test it has been observed that the compressive strength is good and found around $\mathrm{M}-50$ grade with $84 \%$ reading above $45 \mathrm{MPa}$.

Half cell potential test shows that there is no any corrosive activity in $54 \%$ area, whereas around $46 \%$ area has corrosive activity which is uncertain and thus proper care needs to be taken for concrete cover. Vibration test gives the range of vibration of foundation of the structure under acceptable range.

Although all the above test results suggested that the quality of concrete and structure is in good state, structure got distress due to expansion of founding soil which is contaminated from caustic liquor.

To avoid the direct contamination of alumina with founding soil of the structure a proper RCC channel with suitable number of pits all-around the structure are required and in the case of high flow of caustic liquor buster pump may be used to pump out the liquor.

\section{Remedial measures}

On basis of the site visit and non-destructive test results following remedial measures for distressed structures may be taken. 
All the columns ( outer three circumferential row of columns), except inner columns, should be braced at two levels (one at ground level and other at mid-level) with beams (size: $650 \mathrm{~mm}$ × $650 \mathrm{~mm}$, Reinforcement:Top layer - 4 numbers of $20 \mathrm{~mm}$ diameter, Bottom layer - 4 in numbers of $20 \mathrm{~mm}$ diameter, Side face steel: 2 numbers of $20 \mathrm{~mm}$ diameter, Stirrups: 2legged 10 mm diameter @ 150 mm centre to centre, Grade of Concrete M40 and Grade of steel: Fe500 D TMT steel) both circumferential and radial directions. The concrete cover of the columns should be chipped open at the footing level and at mid height to accommodate the longitudinal reinforcement of the beams. The chipped off surface should be cleaned thoroughly to remove any laitance and dust. Care should be taken for proper connection at the junction of brace beans and columns. Suitable bonding agent should be applied at the junction to make proper bond between fresh and old concrete. PCC pedestal of height not less than $750 \mathrm{~mm}$ should be cast around each column in the outer three circumferential row of columns on ground foor/slab. The pedestal (size: $1050 \mathrm{~mm} \times 1050 \mathrm{~mm}$ ) should be anchored to existing column with shear connectors ( 4 nos. with $12 \mathrm{~mm}$ dia (a) $150 \mathrm{~mm} \mathrm{c} / \mathrm{c}$ ) and $12 \mathrm{~mm}$ dia main bars.

The ground floor/slab surrounding the columns to be retrofitted properly with concrete not less than M40 to prevent the further penetration of caustic liquor in the foundation. Proper drainage system should also be provided on the ground slab. Some chemical may also be used to nullify the effect of expansive nature of liquor alumina.

\section{Conclusion}

Following conclusions can be drawn with reference to the preceding discussions on contaminated soil and distressed structures.

Non-Destructive tests may be used to ascertain the health of distressed reinforced cement concrete structure due to degradation of founding soil by chemical contamination.

Physical parameters of concrete and reinforcement such as compressive strength, soundness, rate of steel corrosion have been analysed using NDT equipments.
Ultrasonic test shows most of the concrete is in sound condition with no honeycombing and $73 \%$ falls in good category whereas compressive strength determined from Rebound hammer test is in good range and found around M50 grade of concrete with $84 \%$ reading of hammer test is above $45.0 \mathrm{MPa}$. Half-cell potential test shows that around $54 \%$ area of concrete has no corrosive activity whereas around $46 \%$ area of concrete has the corrosive activity and proper care needs to be taken for concrete cover.

\begin{abstract}
Authors acknowledge to the Hindalco Industries limited, India for providing data of different tests conducted at the site. Above case study has been taken from site visit report prepared by the Department of Civil Engineering, IIT(BHU), Varanasi.
\end{abstract}

\section{Références bibliographiques}

Calace N., Campisi T., lacondini A., Leoni M., Petronio B.M., Pietroletti M. (2005). Metal- contaminated soil remediation by means of paper mill sludges addition: chemical and ecotoxicological evaluation. Environmental Pollution, | 36(3), pp. 485-492. https://doi.org/ | 0. I 0 | 6/j.envpol.2004. 12.014

Report of Site Visit of different RCC structures of Hindalco Industries Limited, India, 2017.

Gratchev I.B., Towhata I. (2009). Effects of acidic contamination on the geotechnical properties of marine soils in Japan. Proceedings of the Nineteenth International Offshore and Polar Engineering Conference, 2 I-26 July, Osaka, Japan. International Society of Offshore and Polar Engineers. https://www. onepetro.org/conference-paper/ISOPE-I-09-466

Thusoo S., Modi K., Kumar R., Madahar H. (2015). Response of buildings with soil-structure interaction with varying soil types. International Journal of Civil and Environmental Engineering, 9(4), pp. 4I4-4I8.

Paulose Shimna, Reddy P. Hari Prasad, Jayakumar K.V (2014). Swell Potential Studies on Soils Contaminated with $\mathrm{NaOH}$ solutions. Proceeding of Indian Geotechnical Conference IGC- 20 I4, December 18-20, Kakinada, India. 